\title{
Fibroblasts from a leprechaun patient have defects in insulin binding and insulin receptor autophosphorylation
}

\author{
J.A.Maassen ${ }^{1}$, M.P.Klinkhamer ${ }^{1}$, G.C.M.van der Zon ${ }^{1}$, H.Sips ${ }^{2}$, W.Möller ${ }^{1}$, H.M.J.Krans ${ }^{2}$, D. Lindhout ${ }^{3}$ and \\ F.A. Beemer ${ }^{4}$ \\ ${ }^{1}$ Department of Medical Biochemistry, Sylvius Laboratories, ${ }^{2}$ Department of Endocrinology and Metabolic Diseases, University Hospital, \\ Leiden, ${ }^{3}$ Department of Cell Biology and Genetics, Erasmus University; Rotterdam, and ${ }^{4}$ Clinical Genetics Center, University of Utrecht, \\ The Netherlands
}

\begin{abstract}
Summary. Leprechaunism is an inherited human disorder associated with an extreme resistance of the target cells towards the action of insulin. We have examined the properties of the insulin receptor in fibroblasts from a leprechaun patient (Geldermalsen, the Netherlands). In vitro, severe insulin resistance is reflected by a low level of insulin stimulated uptake of 2-deoxyglucose by these fibroblasts. This defect seems to be caused by a combination of two factors: a low level of insulin binding to intact cells and a strong decrease of insulin stimulated autophosphorylation of the receptor. The stimulation of autophosphorylation by insulin
\end{abstract}

was approximately six-fold in control subjects and less than two-fold in the patient. No abnormalities were observed in the total number of insulin receptors in these cells and the molecular weights of the receptor subunits. In addition, the insulin concentration required for half maximal autophosphorylation is similar for the solubilised receptor from control and patient fibroblasts.

Key words: Leprechaunism, insulin receptor, autophosphoryllation, insulin binding.
Leprechaunism is a rare human disorder associated with a severe form of insulin resistance of the target cells. The affected newborns have a characteristic facial appearance. They fail to thrive and they lack subcutaneous fat. In general their life span is only a few months [1]. Characterisation of the cellular defect in leprechaunism causing the resistance may help to elucidate the factors involved in the development of much milder forms of insulin resistance like Type 2 (non-insulin-dependent) diabetes mellitus. Also, it may help to develop prenatal tests in specific families at risk for leprechaunism.

Several biochemical studies on cells from leprechaun patients have been reported, especially on leprechaun Ark 1. Although there is a discrepancy between some of these studies, most data indicate in leprechaun Ark 1 a defect linked to the receptor [2-4]. More recent studies of this specific case show a decreased number of receptors on the patient erythrocytes [5]. In addition, the insulin stimulated tyrosine kinase activity of the $\beta$ chain of the receptor is normal in Epstein Barr virus transformed lymphocytes of this patient [6].

We have examined various properties of the insulin receptor in cultured primary fibroblasts from a leprechaun patient (Geldermalsen, The Netherlands).
Subject, materials and methods

The patient (leprechaun Geldermalsen)

The patient, a boy, was the first child of healthy consanguineous parents (inbreeding coefficient $=1 / 128$ ). In the 33rd week of pregnancy, intrauterine growth retardation was noticed and remained progressive despite conservative treatment. Because of placental insufficiency and decelerations in the cardiotocography at the beginning of labour, a caesarean section was performed in the $37 \mathrm{th}$ week. Birthweight was only $1240 \mathrm{~g}$; length $39.5 \mathrm{~cm}$, and the occipitofrontal head circumference $30 \mathrm{~cm}$. The placenta showed extensive in farctions. Four hours after delivery, hypoglycaemia was diagnosed and treated with intravenous glucose infusion. The child had the following dysmorphic features: slightly low implant of large prominent ears, edematous eyelids, upturned nose, prominent philtrum, thickened prominent lips, large penis and scrotal sac. Cranial sutures were widened. The abdomen was distended and tender and there was a lack of subcutaneous fat with wrinkling of skin over the extremities. The hands and feet were apparently large. The clinical course was characterised by frequent episodes of hypo-, normo- and hyperglycaemia, but mostly hypoglycaemia which was treated with intravenous glucose infusion.

Gastrografin clysma demonstrated multiple meconium plugs, and subsequently passage of meconium started. However, chronic feeding difficulties persisted with periods of no-gastrointestinal passage. Laparotomy at the age of 7 weeks showed an almost black liver of normal size and a very small Meckel's diverticulum. Despite parenteral nutrition and careful re-introduction of oral feeding, there 
was a severe failure to thrive. During parenteral nutrition a conjugated hyperbilirubinaemia, slightly elevated serum transaminases, and severe clotting dysfunction was noticed. In the 4th week there was an episode of thermolability accompanied with hypoglycaemia. Congenital infections were excluded. There were several septicaemic periods with haemolytic streptococcus group B, staphylococcus epidermidis, and enterococcus cultured from the blood. Further laboratory examinations showed a clotting dysfunction consistent with either vitamin $\mathrm{K}$ deficiency or hepatic dysfunction and was treated with fresh plasma and vitamin $\mathrm{K}$.

Thyroid function tests indicated a low thyroid binding globulin, probably due to hepatic insufficiency, and unusually low serum thyroglobulin concentration. Serum cortisol day curve was normal. During hypoglycaemia $(0.8 \mathrm{mmol} / 1)$, growth hormone and cortisol levels were normal but the insulin level was elevated $(124 \mathrm{mU} / 1)$. With normal or slightly elevated glucose levels, insulin levels of more than $200 \mathrm{mE} / 1$ were found. Levels of testosteron, luteinising hormone, follicle stimulating hormone, and glucagon were normal. Serum concentrations of immunoglobulins and complement (CH50) were normal. Examination for alpha-1-antitrypsine deficiency and hepatitis-B were negative. Serum ion levels were in the upper range of normal $(20.5 \mathrm{mmol} / \mathrm{l})$, transferrine level was lowered $(1.1 \mathrm{~g} / \mathrm{l})$ and ferritine levels were strongly elevated $(3530 \mu \mathrm{g} / 1)$. The black liver seemed to results from iron deposition which is frequently observed in leprechaun patients. There was a systolic cardiac murmer with ECG signs of left ventricular hypertrophy. Echocardiography showed hypertrophy of the septum and the dorsal wall of the left ventricle with small left ventricular volume. Both kidneys were palpable and proteinuria was frequently noticed. Renal ultrasound was normal but intravenous pyelography showed abnormalities compatible with medullary sponge kidneys.

Cystography showed a flacid and anteriorly displaced bladder. Cytogenetic analysis of peripheral lymphocytes showed a normal male karyotype $(46, \mathrm{XY})$. Profase analysis of cultured fibroblasts showed no deletions of structural abnormalities. The patient died at the age of 7 weeks because of septicaemia and cardiac insufficiency. Permission for post mortem examination was not obtained.

\section{Fibroblast culture}

Human fibroblasts were developed from explants of skin biopsies from the leprechaun patient and three control subjects of the same age and sex. Stock cultures were harvested around the third passage and stored in liquid nitrogen. Cells were grown in F10 medium supplemented with $10 \%$ heat inactivated fetal calf serum in a $2.5 \%$ $\mathrm{CO}_{2}$ atmosphere.

\section{Insulin and insulin like growth factor I binding}

Fibroblasts were grown in $6 \mathrm{~cm}$ tissue culture dishes to confluency. Insulin binding was performed at cells from various passages. No effect of the passage number was observed. For binding, the cells were washed twice with $5 \mathrm{ml}$ of PBS-2\% BSA, pH 7.8 followed by incubation in $500 \mu \mathrm{l}$ of the same medium containing $3.10^{-11} \mathrm{~mol} / 1$ $\left[{ }^{125} \mathrm{I}\right]$ iodoinsulin(A14-iodotyrosyl, $2000 \mathrm{Ci} / \mathrm{mmol}$, Amersham, Buckinghamshire, UK) for $1 \mathrm{~h}$ at $22^{\circ} \mathrm{C}$. Cells were washed five times with icecold PBS-BSA, dissolved in $2 \mathrm{ml}$ of $1 \%$ NP40 and radioactivity was determined in a $\gamma$-counter. Non-specific binding was determined by the addition of $1 \mu \mathrm{mol} / 1$ insulin (NOVO, monocomponent, Bagsvaerd, Denmark) to the radioactive tracer. This value was approximately $40 \%$ of total radioactivity bound to control fibroblasts. Binding of $\left[{ }^{125} \mathrm{I}\right]$ insulin like growth factor I (IGF-I) was performed as described for insulin binding. The level of non specific binding was in most cases determined by addition of $10^{-5} \mathrm{~mol} / 1$ insulin instead of IGF-1, due to the limited availability of IGF-I.

\section{Uptake of 2-deoxyglucose (2-DOG)}

Fibroblasts were grown in $6 \mathrm{~cm}$ dishes until they just reached confluency. Twenty-four $h$ before assaying 2-DOG uptake, fresh medium was added to the cells. The cells were washed 5 times with phosphate buffered saline and $1.5 \mathrm{ml}$ of $50 \mathrm{mmol} / 1$ hydroxyethyl piperazinyl ethane sulphonic acid (HEPES), pH 7.4, $120 \mathrm{mmol} / 1 \mathrm{NaCl}$, $1.3 \mathrm{mmol} / 1 \mathrm{MgSO}_{4}, 1,85 \mathrm{mmol} / 1 \mathrm{CaCl}_{2}, 4.8 \mathrm{mmol} / 1 \mathrm{KCl}$ containing insulin at concentrations indicated, was added. Incubation was for $1 \mathrm{~h}$ at $37^{\circ} \mathrm{C}$. Subsequently, 2-DOG $\left(1-{ }^{14} \mathrm{C}\right.$, spec. activity 4 $\mathrm{mCi} / \mathrm{mmol}$ ) was added at a concentration of $7.5 \mu \mathrm{mol} / 1$ and incubation was continued for $10 \mathrm{~min}$ at $37^{\circ} \mathrm{C}$. Uptake of 2-DOG was terminated by addition of $5 \mathrm{ml}$ of icecold phosphate buffered saline, followed by five washes with $5 \mathrm{ml}$ of icecold phosphate buffered saline. Cells were lysed in $1 \mathrm{ml}$ of $0.1 \mathrm{~mol} / 1 \mathrm{NaOH}$ and ${ }^{14} \mathrm{C}$ content was measured by liquid scintillation counting. Protein concentration was determined by the Bradford method (Biorad protein assay kit, Richmond, California USA) and 2-DOG uptake was normalised on protein content.

\section{Insulin stimulated autophosphorylation of the receptor}

Control and leprechaun fibroblasts were grown to confluency and the glycoprotein fraction was isolated essentially as described by chromatography over wheat germ agglutinin-sepharose [7]. The glycoprotein fraction was obtained in WgA-buffer $(50 \mathrm{mmol} / 1 \mathrm{HEPES}$, $\mathrm{pH} 7.4,10 \mathrm{mmol} / 1 \mathrm{MgCl}_{2}, 1 \mathrm{mmol} / 1$ 2-mercaptoethanol, $0.1 \%$ Triton $\mathrm{X} 100,1 \mathrm{kU} / \mathrm{ml}$ Trasylol, $1 \mu \mathrm{g} / \mathrm{ml}$ leupeptin, $0.1 \mathrm{mmol} / 1$ phenyl methyl sulphonyl fluoride, $0.3 \mathrm{~mol} / 1 \mathrm{~N}$-acetylglucosamine). Protein concentration was determined by the Bradford method (Biorad). Glycoprotein concentration was adjusted to $1 \mathrm{mg} / \mathrm{ml}$ by addition of WgA buffer and bovine serum albumin (Boehringer Mannheim, Mannheim, FRG, molecular biology grade) was added to $1 \mathrm{mg} / \mathrm{ml}$. Insulin (Novo, human monocomponent, Bagsvaerd Denmark) was added to $10 \mu \mathrm{l}$ of glycoprotein fraction and incubation was for $1 \mathrm{~h}$ at $22^{\circ} \mathrm{C}$. Phosphorylation was initiated by addition of $\mathrm{MnCl}_{2}$ (final concentration $6 \mathrm{mmol} / \mathrm{l}$ ) and $\gamma\left[{ }^{32} \mathrm{P}\right]$ ATP (final concentration $25 \mu \mathrm{mol} / \mathrm{l} ; 150 \mathrm{Ci} / \mathrm{mmol}$ ), the final incubation volume being $15 \mu \mathrm{l}$. Incubation was for $6 \mathrm{~min}$ at $22^{\circ} \mathrm{C}$. The reaction was terminated by addition of $1 \mathrm{ml}$ of $10 \%$ trichloroacetic acid. The protein pellet was washed with $1 \mathrm{ml}$ of ethanol and dissolved in $50 \mu \mathrm{l}$ of $50 \mathrm{mmol} / 1 \mathrm{NaHCO}_{3}-0.1 \%$ sodium dodecyl sulphate for immune precipitation and autoradiography. Fibroblasts from three different individuals (age and sex matched) were used as controls.

\section{Immune precipitation}

$700 \mu \mathrm{l}$ of immune precipitation buffer $(50 \mathrm{mmol} / \mathrm{I}$ TRIS- $\mathrm{HCl}$, $\mathrm{pH} 7.6,200 \mathrm{mmol} / 1 \mathrm{NaCl}, 10 \mathrm{mmol} / \mathrm{l}$ EDTA, $10 \mathrm{mmol} / 1 \mathrm{NaF}$, $5 \mathrm{mmol} / 1$ p-nitrophenylphosphate, $1 \% \mathrm{NP} 40,1 \mu \mathrm{g} / \mathrm{ml}$ leupeptin, $1 \mathrm{kU} / \mu \mathrm{l}$ Trasylol) was added to the solubilised protein followed by five $\mu$ l of rabbit anti-receptor serum [8]. Incubation was for $16 \mathrm{~h}$ at $4^{\circ} \mathrm{C}$. Twenty-five $\mu \mathrm{l}$ of $10 \%$ Staphylococcus aureus suspension was added and after $30 \mathrm{~min}$ at $4^{\circ} \mathrm{C}$, the immune complex was isolated by centrifugation, washed twice with $1 \mathrm{ml}$ of immune precipitation buffer and protein was analysed by sodium dodecyl sulphate-polyacrylamide gel electrophoresis and autoradiography on preflashed Kodak XAR 5 films. The autoradiograms were analysed by densitometrical scanning using a Joyce Loebl densitometer.

\section{Cross linking}

Fifty $\mu \mathrm{g}$ of glycoprotein was incubated for $16 \mathrm{~h}$ at $0^{\circ} \mathrm{C}$ in $100 \mu \mathrm{l}$ of WgA buffer containing $\left.9 \mathrm{nmol} / 1 \mathrm{I}^{125} \mathrm{I}\right]$ iodoinsulin $(2000 \mathrm{Ci} / \mathrm{mmol})$. Cross-linking was induced by the addition of disuccinimidyl sube- 
rate $(1 \mathrm{~mol} / \mathrm{l})$ in dry dimethylsulphoxide to a final concentration of $0.2 \mathrm{mmol} / 1$. After $10 \mathrm{~min}$ at $0^{\circ} \mathrm{C}$, the mixture was made $50 \mathrm{mmol} / 1$ in Tris- $\mathrm{HCl}$, pH 7.8 followed by addition of $1 \mathrm{ml}$ of $10 \%$ trichloroacetic acid and the protein precipitate was processed for immune precipitation.

\section{Northern blot analysis}

This was performed as described previously [8] using $30 \mu \mathrm{g}$ of total cellular RNA.

\section{Statistical analysis}

Results are expressed as mean values \pm standard deviations for at least three independently performed experiments. Differences between control and patient values were evaluated by Student's $t$ test.

\section{Results}

The levels of specific binding of $\left[{ }^{125} \mathrm{I}\right]$ insulin to control and leprechaun fibroblasts are shown in Figure $1 \mathrm{a}$. Binding was performed at various $\mathrm{pH}$ values. It was seen that binding of insulin to the patient's fibroblasts was significantly decreased at the $\mathrm{pH}$ values of 7.8 and $8.2(p<0.001$ at $\mathrm{pH} 7.8)$. A similar $\mathrm{pH}$ dependence of insulin binding has been observed with another leprechaun patient [3]. Figure $1 \mathrm{~b}$ shows the levels of total binding of $\left[{ }^{125} \mathrm{I}\right]$ insulin to the patients fibroblasts, together with the binding levels to fibroblasts from three controls. Also, the levels of non-specific binding, i. e. the radioactivity which is not competed away by $10^{-6} \mathrm{~mol} / 1$ insulin, are shown. We have also performed binding experiments with IGF-1. Similar binding values were obtained in case of fibroblasts from control persons and the patient (approximately $0.8 \mathrm{fmol}$ IGF-1 bound per $10^{6}$ cells at an IGF- 1 concentration of $2.7 \cdot 10^{-11} \mathrm{~mol} / \mathrm{l}$ ).

Examination of the stimulation of 2-DOG uptake by insulin in fibroblasts from control tissues and the patient reveals a strongly impaired stimulation of hexose uptake in the patient's cells (Fig.2). The absolute values of 2-DOG uptake both with and without insulin are depicted in Figure 3 . We observed frequently that the basal level of 2-DOG uptake in the patient's fibroblasts was higher than in control cells. No significant effect of the passage number was observed on the insulin stimulated 2-DOG uptake.

The impaired binding of insulin to the patient's fibroblasts could be the sole cause for impaired hexose transport. However, other factors like a defective signal transduction mechanism could also contribute to the observed insulin resistance. The insulin stimulated autophosphorylation of the $\beta$ chain of the insulin receptor is considered to reflect the transduction of the signal triggered by insulin binding [9-12]. We have quantitated this property of the receptor from the leprechaun patient. For that purpose, the receptor was partially purified by solubilisation of the leprechaun fibroblasts in the non-ionic detergent TRITON X100, followed by isolation of the glycoprotein fraction by chromatography over wheat germ agglutinin sepharose. In a parallel experiment control fibroblasts were used for isolating the glycoprotein fraction. The glycoprotein fractions were used for titration of $\beta$ chain autophosphorylation by increasing levels of insulin in the presence of $\gamma\left[{ }^{32} \mathrm{P}\right] \mathrm{ATP}$. The labelled receptor was purified by immune precipitation and analysed by sodium dodecyl sulphate-polyacrylamide gel electrophoresis and autoradiography. Figure $4 \mathrm{a}$ shows the autoradiogram of the experiments with material from leprechaun fibroblasts. Also, the results are shown obtained at insulin concentrations of 0 and $10^{-6} \mathrm{~mol} / 1$ with material from control fibroblasts. It is obvious that the maximum level of $\beta$ chain labelling was strongly decreased. In addition, the stimulation of autophosphorylation by insulin was approximately six-fold in control tissues, whereas in the patient the stimulation was less than two-fold. Remarkably, $\beta$ subunit labelling without insulin tended to be consistently higher in the leprechaun compared to control tissues. This phenomenon was repeatedly observed with different glycoprotein preparations. Quantitation of $\beta$
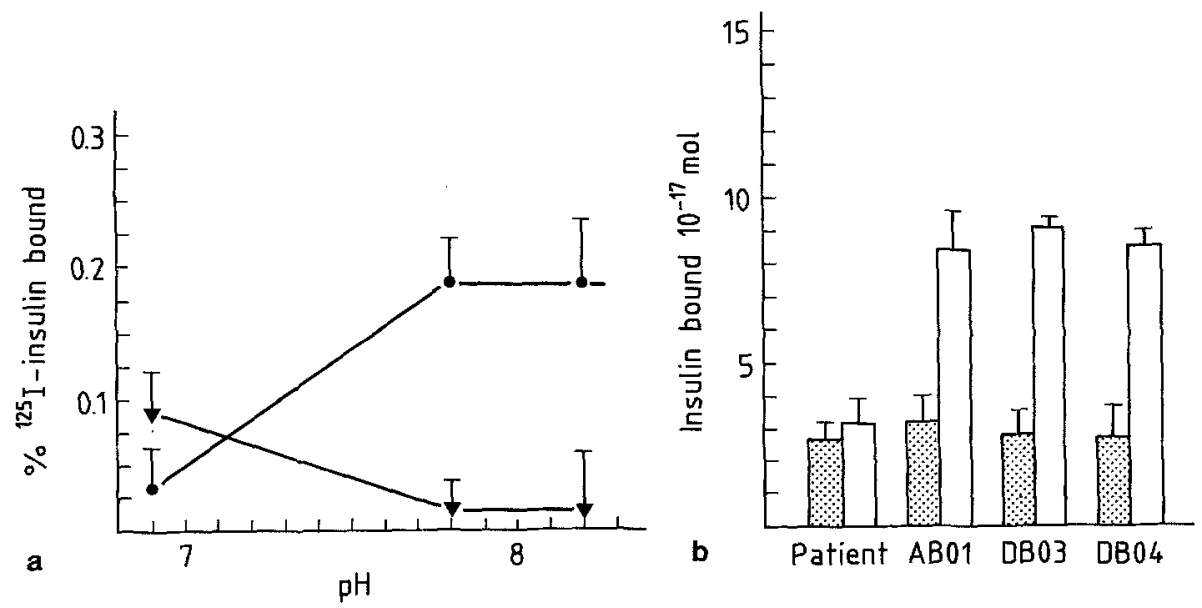

Fig. 1a. Specific binding of $\left[{ }^{125}\right.$ I] Insulin to fibroblasts from control (--) and leprechaun (- - -) at various $\mathrm{pH}$ values. Standard deviations are indicated. $\mathbf{b}\left[{ }^{125} \mathrm{I}\right]$ insulin binding to fibroblasts from the leprechaun patient and three control tissues (ABO1, DBO3 and DBO4). Binding was performed at a $\mathrm{pH}$ of 7.8 . Open bars ( $\square$ ) represent total binding of radioactivity and filled bars ( $)$ represent radioactivity bound in the presence of $10^{-6} \mathrm{~mol} / 1$ nonradioactive insulin. Standard deviations are indicated 
chain labeling resulted in a dose response curve shown in Figure $4 \mathrm{~b}$. The maximal ${ }^{32} \mathrm{P}$ incorporation was strongly decreased in this patient, which makes a determination of the insulin concentration for half maximal effect less accurate; though this insulin concentration seems to be near $10^{-9} \mathrm{~mol} / \mathrm{l}$ in both leprechaun and control tissues.
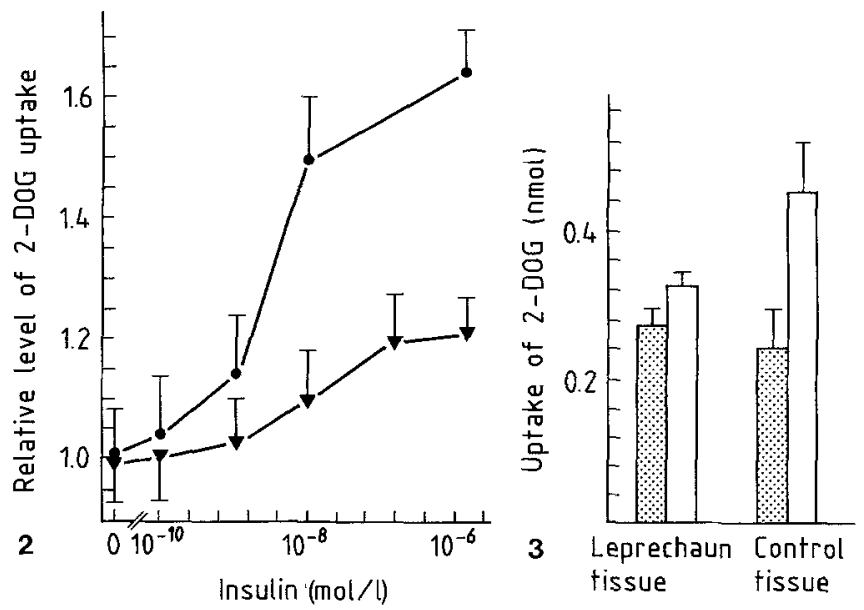

Fig. 2. Insulin stimulated uptake of 2-DOG in fibroblasts from con-

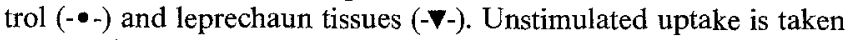
at a relative value of 1 . Standard deviations are indicated

Fig. 3. Absolute levels of 2-DOG uptake in fibroblasts $\left(8.10^{5}\right.$ cells) from control tissues and the leprechaun patient tissues in the absence of insulin (ㅁ) and in the presence of $10^{-6} \mathrm{~mol} / \mathrm{l}$ insulin ( $\square$ ). Control represents the averaged data obtained with fibroblasts from three non-diabetic individuals
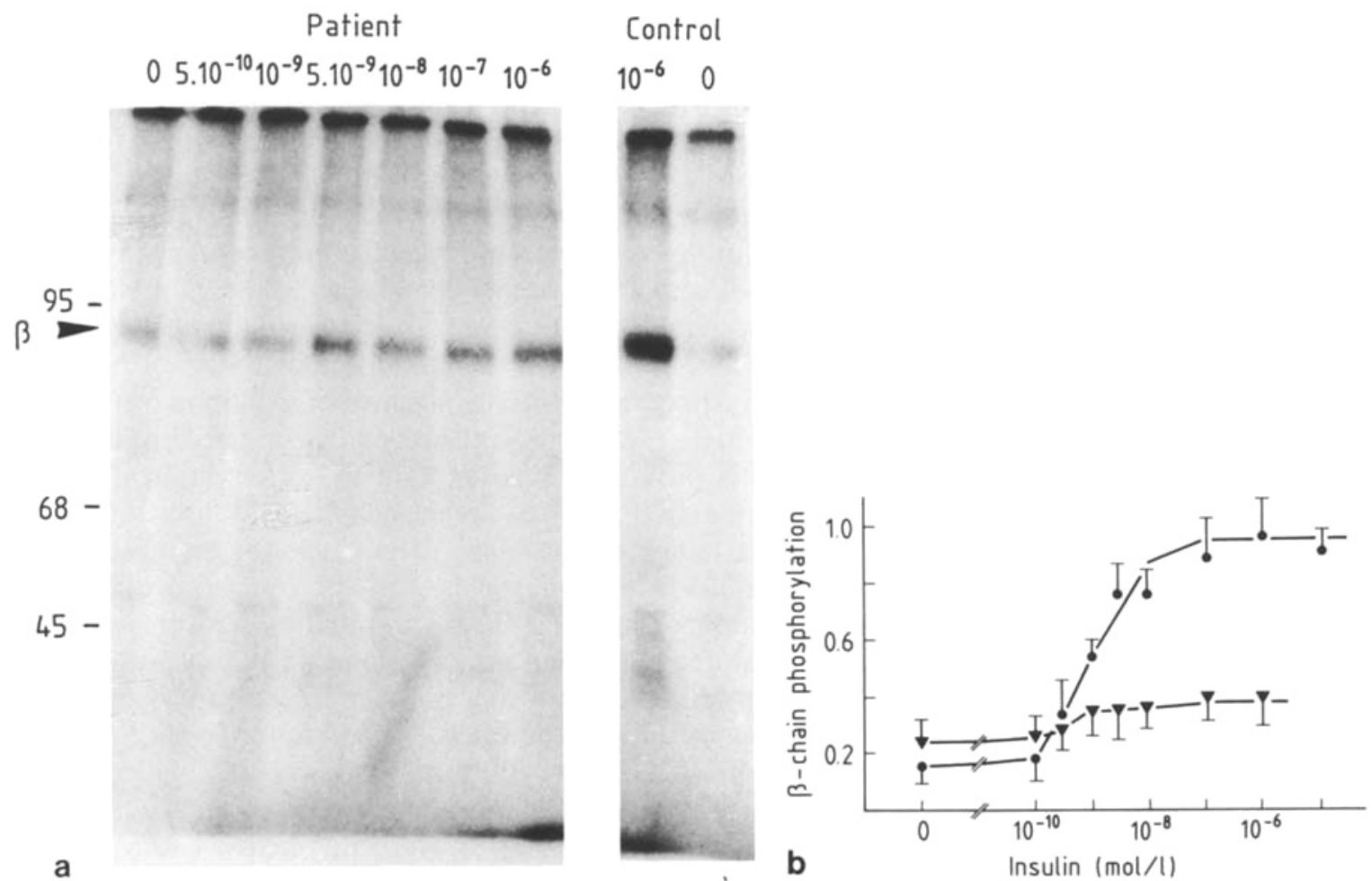

Fig.4a. Analysis by sodium dodecylsulphate polyacrylamide gel electrophoresis and autoradiography of the insulin stimulated autophosphorylation of the receptor $\beta$ chain from fibroblasts from the patient and control. b Quantitation of $\beta$ chain labelling of the receptor from control $(\bullet)$ and leprechaun Geldermalsen $(\nabla)$ by densitometry of the autoradiograms $(n \geq 3)$ and by Cerenkov counting of the excised $\beta$ subunit bands. Standard deviations are indicated. Maximal labelling corresponds to $0.1 \mathrm{fmol}{ }^{32} \mathrm{P}$ incorporated / $10 \mu \mathrm{g}$ of protein
The normal electrophoretic behaviour at a $\mathbf{M}_{\mathbf{r}}$ of $93 \mathrm{kD}$ of the ${ }^{32} \mathrm{P}$ labelled $\beta$ chain of the receptor from the patient indicates the absence of mutations leading to detectable variations in molecular weight.

We also determined the molecular weight of the $\alpha$ chain of the receptor and the number of receptor molecules in the glycoprotein fraction. This was done by cross-linking $\left[{ }^{125} \mathrm{I}\right]$ insulin to the $\alpha$ subunit by the bifunctional cross-linker disuccinimidyl suberate using glycoprotein fractions from leprechaun and control fibroblasts. Judged from the titration experiments of receptor autophosphorylation, the solubilised leprechaun receptor had a normal affinity for insulin. Therefore, the yield of cross-linked product will reflect the receptor concentration in the glycoprotein fraction. After cross-linking, the receptor was immune precipitated and analysed by sodium dodecyl sulphate-polyacrylamide gel electrophoresis and autoradiography. normal molecular weight of the $\alpha$ chain was detected. Analysis of the autoradiogram by densitometry, which eliminates variations in background, shows that the incontrol and patient lane. This indicates a similar yield of cross-linked receptor-insulin complex. Examination of the level of insulin receptor-mRNA in total RNA from control and leprechaun fibroblasts by Northern blotting showed no major differences (Fig.6) corroborating a normal receptor number. We also measured the mRNA levels for IGF-1 receptors by hybridisation Figure 5 shows the resulting autoradiogram. No abtensities of the labelled $\alpha$ subunits were similar in the 


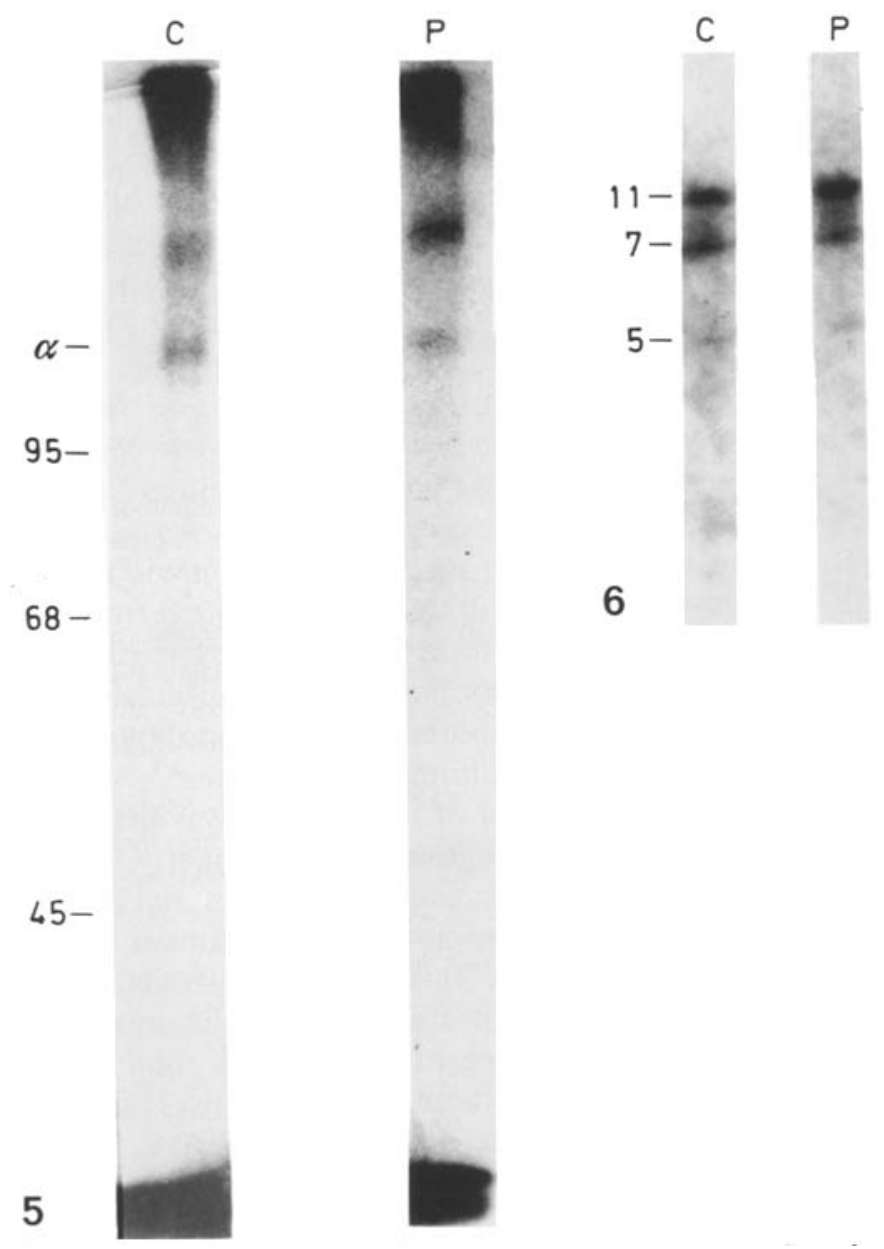

Fig.5. Sodium dodecyl sulphate polyacrylamide gel electrophoresis and autoradiography of $\left.{ }^{125} \mathrm{I}\right]$ labelled $\alpha$ chain of the insulin receptor from control $(\mathrm{C})$ and patient $(\mathrm{P})$ fibroblasts. $\left[{ }^{125} \mathrm{I}\right]$ Insulin was crosslinked to the solubilised receptor by disuccinimidyl suberate as described in Subject, materials and methods. $M_{r}$ in $\mathrm{Kd}$ are indicated. The samples were reduced with mercaptoethanol prior to electrophoresis

Fig.6. Quantitation of insulin receptor-mRNA levels in $30 \mu \mathrm{g}$ of total RNA from control $(C)$ and leprechaun patient $(\mathrm{P})$ fibroblasts by Northern blot. Hybridisation was with a nick translated insulin receptor-cDNA probe [8] representing nucleotide 3956-4476, numbering according to [17]. Hybridisation and washing conditions were as described [8]. Size in $\mathrm{kb}$ is indicated and derived from the positions of rat $18 \mathrm{~S}$ and $28 \mathrm{~S}$ rRNA. After hybridisation of the filters with the receptor probe, the filters were rehybridised subsequently with labelled cDNA probes for $\gamma$-actin and human elongation factor $I$. No significant differences were observed in the levels of these mRNAs between control and the leprechaun patient

of the Northern blots with a cDNA probe for the IGF1 receptor. No abnormality was observed in the patient's fibroblasts (not shown).

\section{Discussion}

We performed the investigations on primary fibroblasts from the leprechaun patient. Cells were available both from the patient and control tissues and they show an insulin stimulated uptake of glucose. Insulin receptor studies on fibroblasts are complicated by the presence of an excess of IGF-1 receptors with respect to insulin receptors [13]. These receptors show a strong sequence homology and the subunits have a similar mobility on gels [14]. In addition, their ligands show a certain degree of cross-binding. In the present study the insulin receptor was purified by immune precipitation prior to analysis. Therefore, we tested the antibody for cross reactivity with IGF-1 receptors. This was done by immune precipitation experiments on the labelled human teratocarcinoma celline Tera-2. This celline has approximately $10^{4}$ IGF- 1 receptors and no insulin receptors on the cell surface. No significant cross-reactivity of our antiserum with IGF-1 receptors was observed (not shown). In addition, some immune precipitations were also performed with another antireceptor serum (B9) showing identical results. This finding argues also against the possibility that the receptor from the patient may have lost a specific epitope, resulting in a different immunologic behaviour with different antisera. Such a situation has been described with another patient [6].

Cellular resistance for the action of insulin in the leprechaun patient Geldermalsen is obvious from the in vitro results on insulin binding and 2-DOG uptake. The solubilised cells seemed to contain a normal number of receptors with a normal affinity for insulin. However, signal transduction was strongly impaired as judged from the decreased maximum of insulin stimulated autophosphorylation and from the observation that the insulin stimulated increase in $\beta$-chain autophosphorylation was less than two-fold in the patient compared to approximately six-fold in control tissues. The decrease in the stimulation of autophosphorylation cannot be caused by a misjudgment of the number of insulin receptors in the glycoprotein fraction from this patient as this stimulation does not require knowledge of the actual receptor concentration. The autophosphorylation of the insulin receptor at tyrosine residues is considered to reflect the receptor's activity for signal transduction resulting in enhanced glucose uptake [9-12]. It is remarkable that the level of autophosphorylation in the absence of insulin is consistently higher in the patient's receptor compared to control. This difference may explain the observation that unstimulated 2-DOG uptake was consistently higher in the patient's fibroblasts. The cause for the absence of insulin action may reside in the low level of insulin binding to these cells in combination with the lowered autophosphorylation. Low binding of insulin can result either from a low number of receptors or from a low affinity of the plasma membrane receptors for insulin. We have tried to distinguish between these possibilities by analysing the binding data according to Scatchard. The results were inconclusive due to the very low level of insulin binding and the resulting large variations in binding data. Fibroblasts also contain a relatively large number of IGF-1 receptors on the cell surface. These receptors bind insulin with a significant 
affinity, complicating the interpretation of Scatchard plots. We have observed that fibroblasts from this leprechaun patient bind IGF-1 to the same extent as control cells. This observation stresses that the defect in this patient seemed to be confined to the insulin receptor itself. A similar finding with another leprechaun patient has been described [15].

We have described recently the properties of the insulin receptor from another leprechaun patient (leprechaun Helmond) [16]. A common property of the fibroblasts from both patients is a low level of insulin binding and the impaired uptake of 2-DOG. After solubilisation, fibroblasts from both patients show a normal number of insulin receptors and the solubilised receptors have a normal affinity for insulin as judged from the autophosphorylation experiments. The maximum level of autophosphorylation is normal in leprechaun Helmond in contrast to the situation in leprechaun Geldermalsen.

It is remarkable that in both cases insulin binding to intact fibroblasts is low, although the receptor is present in normal amounts in the cells and is also expressed on the cell surface, at least in leprechaun Helmond. These observations indicate a decreased affinity for insulin of the receptors on the cell surface. However, a normal afinity is observed after solubilisation. Such a situation may result from the presence of a non-covalently associated factor to the receptor. Solubilisation by detergent disrupts this complex and the low affinity state is converted into a normal one. Alternatively, the receptor has an abberant primary structure which prevents folding in the proper conformation when present on the plasma membrane. This constraint is released by solubilisation with detergent. Molecular cloning of the receptor and expression of the patient's receptor cDNA clone may answer the question whether the defect is localised in the insulin receptor or secondary to it.

Acknowledgement. This work was supported by the Netherlands Organization for the Advancement of Pure Research (ZWO) through the Foundation for Medical Research (MEDIGON) and the Diabetes Fonds Nederland. We wish to thank Dr. C.R. Kahn for his gift of B9 anti receptor serum and R.H.Lekanne Deprez for performing IGF-1 binding experiments.

\section{References}

1. Donohue WL, Uchida T (1954) Leprechaunism, a euphemism for a rare familial disorder. J Pediatrics 45: 505-519

2. Knight AB, Rechler MM, Romanus JA, van Obberghen-Schilling, Nissley SP (1981) Stimulation of glucose incorporation and amino acid transport by insulin and insulin-like growth factor in fibroblasts with defective insulin receptor cultured from a patient with leprechaunism. Proc Natl Acad Sci USA 78: 2554-2558

3. Taylor SA, Hedo JA, Underhill LH, Kasaga M, Elders MJ, Roth J (1982) Abnormally high binding affinity of insulin receptors from a patient with leprechaunism. Evidence for a defect intrinsic to the receptor. J Clin Endocrinol Metab 55: 1108-1113
4. Elsas LJ, Endo F, Strumlauf E, Elders J, Priest JH (1985) Leprechaunism: an inhereted defect in a high-affinity insulin receptor. Am J Hum Gen 37: 73-88

5. Grigorescu F, Herzberg V, King G, Meistas M, Elders J, Frazer T, Kahn CR (1987) Defects in insulin binding and autophosphorylation of erythrocyte insulin receptor in patients with syndromes of severe insulin resistance and their parents. $J$ Clin Endocrinol Metab 64: 549-556

6. Cama A, Taylor SI (1987) Tyrosine kinase activity of insulin receptors from an insulin resistant patient. Diabetologia 30: 631-637

7. Maron R, Kahn CR, Jacobs S, Fujita-Yamaguchi Y (1984) Visualization of the insulin receptor by immunoblotting. Diabetes 33: 923-928

8. Maassen JA, Krans HMJ, Möller W (1987) The effect of insulin, serum and dexamethasone on mRNA levels for the insulin receptor in the human lymphoblastoic cell line IM-9. Biochim Biophys Acta 930: 72-78

9. Chou CK, Dull TJ, Russell DS, Gerzi R, Lebwohl D, Ultrich A Rosen OM (1987) Human insulin receptors mutated at the ATP binding site lack protein tyrosine kinase activity and fail to mediate post receptor effects of insulin. J Biol Chem 262; 1842-1847

10. Morgan DO, Roth RA (1987) Mapping surface structures of the human insulin receptor with monoclonal antibodies: localization of the main immunogenic regions to the receptor kinase domain, Proc Natl Acad Sci USA 84: 41-45

11. Freidenberg GR, Henry RR, Klein HH, Reichart DR, Olefsky JM (1987) Decreased kinase activity of insulin receptors from adipocytes of non-insulin dependent diabetic subjects. J Clin Invest 79: 240-250

12. White MF, Kahn CR (1984) The insulin receptor and tyrosine phosphorylation. In: Boyer PD, Krebs EG (eds) The enzymes, Vol XVII. Academic Press, New York London, pp 247 309

13. Taylor SI, Underhill LH, Hedo JA, Roth J, Serrano Rios M, Blizzard RM (1983) Decreased insulin binding to cultured cells from a patient with the Rabson Mendenhall syndrome: dichitomy between studies with cultured lymphocytes and cultured fibroblasts. J Clin Endocrinol Metab 56: 856-861

14. Ullrich A, Gray A, Tam AW, Yang Feng $T$, Tsubokawa $M$, Collins C, Henzol W, Le Bon T, Kathuria S, Chen E, Jacobs S, Francke U, Ramachandran J, Fujita-Yamaguchi Y (1986) Insulin-like growth factor 1 receptor primary structure: comparison with insulin receptor suggests structural determinants that define functional specificity. EMBO J 5: 2503-2512

15. Podskalny JM, Kahn CR (1982) Cell culture studies on patients with extreme insulin resistance. I. Receptor defects on cultured fibroblasts. J Clin Endocrinol Metab 54: 261-275

16. Maassen JA, Klinkhamer MP, Odink RJH, Sips H, Van Der Zon GCM, Wieringa Tj, Krans HMJ, Möller W (1988) Improper expression of insulin receptors on fibroblasts from a leprechaun patient. Eur J Biochem 172: 725-729

17. Ullrich A, Bell JR, Chen EY, Herrera R, Petruzelli LM, Dull TJ, Gray A, Coussers L, Liao Y, Tsubokawa M, Mason A, Seeburg PH, Grunfeld C, Rosen PM, Ramachandran J (1985) Human insulin receptor and its relationship to the tyrosine kinase family of oncogenes. Nature 313: 756-761

Received: 23 December 1987

and in revised form: 19 April 1988

Dr. J.A. Maassen

Department of Medical Biochemistry

Sylvius Laboratories

Wassenaarseweg 72

NL-2333 AL Leiden

The Netherlands 